\title{
Transgenic Art
}

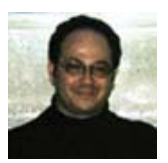

Eduardo Kac

Professor of Art and Technology (School of the Art Institute of Chicago)

ekac@artic.edu

\begin{abstract}
We have become accustomed to technology having a say in the make-up of our aesthetic values, as plastic surgery and the medium of television demonstrate, but genetic engineering opens the way for the new concept of transgenic art, located under the skin and providing for unimagined possibilities. However, apart from the creations that biological art will produce for us via the implantation of artificial genes in the genome of a given species, what will really count will be the relationship between the artist, their work and the end receiver of the new being. GFP K-9 is a good example of transgenic art: a completely normal dog, except that his hair is fluorescent green, thanks to a protein borrowed from a jellyfish. However innovative transgenic art may seem, it should not be forgotten that Man has had a hand in the appearance of new species of dogs, and in all probability in the creation of the dog as a domestic animal, since time immemorial. Another example of the creation of new species are hybrid organisms, whether plants or animals, for practical or merely decorative purposes. There are also the pipe dreams that have formed part of the collective imagination for thousands of years and are now here with us, thanks to biotechnology. In addition, genetic engineering allows the genome to be designed artificially, without any need to start from the genetic material of a particular species. An ethical, responsible perspective should always be behind such creations, a perspective far removed from all-powerful financial criteria, given the profound social repercussions that they can lead to. In any case, transgenesis will be an integral part of our lives-with applications in food processing, aesthetics and medicine-and will even call into question our concepts of species and what is human.
\end{abstract}

New technologies culturally mutate our perception of the human body from a naturally self-regulated system to an artificially controlled and electronically transformed object. The digital manipulation of the appearance of the body (and not of the body itself) clearly expresses the plasticity of the newly formed and multifariously configured identity of the physical body. We observe this phenomenon regularly through media representations of idealized or imaginary bodies, virtual-reality incarnations, and network projections of actual bodies (including avatars). Parallel developments in medical technologies, such as plastic surgery and neuroprosthesis, have ultimately allowed us to expand this immaterial plasticity to actual bodies. The skin is no longer the immutable barrier that contains and defines the body in space. Instead, it becomes the site of continuous transmutation. While we try to cope with the staggering consequences of this ongoing process, it is equally urgent to address the emergence of biotechnologies that operate beneath the skin (or inside skinless bodies, such as bacteria) and therefore out of sight. More than make visible the invisible, art needs to raise our awareness of what firmly remains beyond our visual reach but which, nonetheless, affects us directly. Two of the most prominent technologies operating beyond vision are digital implants and genetic engineering, both poised to have profound consequences in art as well as in the social, medical, political, and economic life of the next century.

$-1-$

(C) FUOC, 2001
ISSN 1695-5951 Legal deposit B-52019-2002 $\neg U O C$ 
Transgenic art, I propose, is a new art form based on the use of genetic engineering techniques to transfer synthetic genes to an organism or to transfer natural genetic material from one species into another, to create unique living beings ${ }^{[1]}$. Molecular genetics allows the artist to engineer the plant and animal genome and create new life forms. The nature of this new art is defined not only by the birth and growth of a new plant or animal but above all by the nature of the relationship between artist, public, and transgenic organism. Organisms created in the context of transgenic art can be taken home by the public to be grown in the backyard or raised as human companions. With at least one endangered species becoming extinct every day ${ }^{[2]}$, I suggest that artists can contribute to increase global biodiversity by inventing new life forms. There is no transgenic art without a firm commitment to and responsibility for the new life form thus created. Ethical concerns are paramount in any artwork, and they become more crucial than ever in the context of bio art. From the perspective of interspecies communication, transgenic art calls for a dialogical relationship between artist, creature/artwork, and those who come in contact with it.

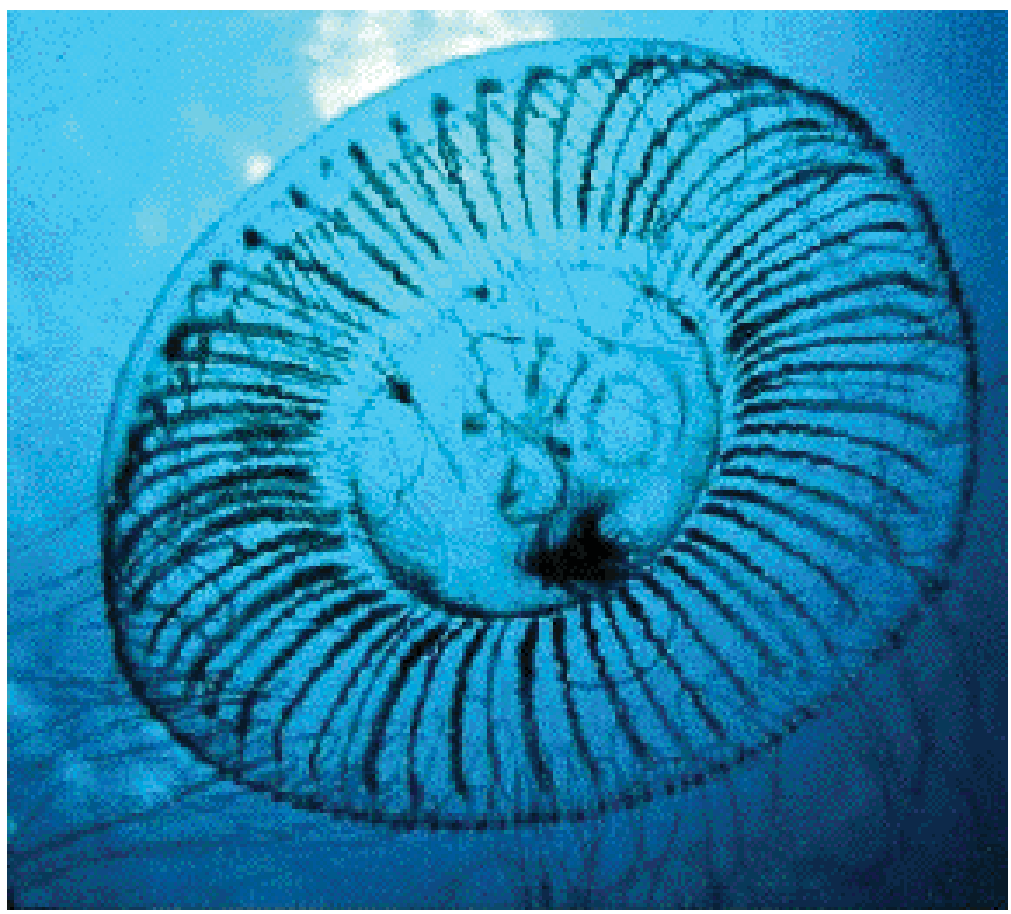

\section{Jellyfish (Aequorea Victoria) Photo: David Wrobel}

Among the most common domesticated of mammals, the dog is a quintessentially dialogical animal; it is not self-centered, it is empathic, and it is often prone to extroverted social interaction $^{[3]}$. Hence, my current work: GFP K-9. GFP stands for Green Fluorescent Protein, which is isolated from Pacific Northwest jellyfish (Aequorea Victoria) and which emits bright green light when exposed to UV or blue light ${ }^{[4]}$. Wild type Aequorea GFP absorbs light maximally at $395 \mathrm{~nm}$ and the fluorescence emission spectrum peaks at $510 \mathrm{~nm}^{[5]}$. The protein itself is 238 amino acids in length. The use of the Green Fluorescent Protein in a dog is absolutely harmless, since GFP is species independent and requires no additional proteins or

1. George Gessert, an artist who works with plant hybridization, identified Edward Steichen, well known for his photographic work, as the first artist to propose and produce genetic art. See: GESSERT, G. (1993). "Notes on Genetic Art". Leonardo. Vol. 26. No. 3, p. 205. Indeed, in 1949 Steichen wrote: "The science of heredity when applied to plant breeding, which has as its ultimate purpose the aesthetic appeal of beauty, is a creative act". Quoted in: GEDRIM, R. J. (1993, Winter). "Edward Steichen's 1936 Exhibition of Delphinium Blooms". In: History of Photography. Vol. 17. No. 4, pp. 352-363. Also contributing to the development of genetic art is Joe Davis, a contemporary artist who works with DNA synthesis technologies. See: DAVIS, J. "Microvenus," special issue of Art Journal Vol. 55, No. 1 (Spring 1996), pp. 70-74.

2. According to the World Wildlife Federation the top 10 most endangered species are: 1. Black Rhino; 2. Giant Panda; 3. Tiger; 4. Beluga Sturgeon; 5. Goldenseal; 6. Alligator Snapping Turtle; 7. Hawksbill Turtle; 8. Big Leaf Mahogany; 9. Green-Cheeked Parrot; 10. Mako Shark.

3. VON KREISLER, K. (1997). The Compassion of Animals. Rocklin, CA: Prima Publishing. This book is a compilation of informal accounts of the sympathy, kindness and loyalty of dogs and other animals towards species other than their own. For a specific discussion of human-canine interaction, see: SERPELL, J. (ed.). (1996). The Domestic Dog: Its Evolution, Behaviour, and Interactions with People. Cambridge; New York: Cambridge University Press; and WENDT, L. M. (1996). Dogs: A Historical Journey: The Human/Dog Connection Through the Centuries. New York: Howell Book House.

4. CHALFIE, M.; TU, Y.; EUSKIRCHEN, G.; WAARD, W.W. and PRASHER, D.C. (1994). "Green fluorescent protein as a marker for gene expression". Science. 263: 802-805; INOUYE, S.; TSUJI, F. I. (1994). "Aequorea green fluorescent protein. Expression of the gene and fluorescence characteristics of the

recombinant protein". FEBS Letters. 341: 277-280

5. WARD, W. W.; CODY, C. W.; HART, R. C. and CORMIER, M. J. (1980). "Spectrophotometric identity of the energy-transfer chromophores in Renilla and Aequorea green fluorescent protein". Photochem. Photobiol, 31: 611-615. 
substrates for green light emission. GFP has been successfully expressed in several host organisms and cells such as E. coli, yeast, and mammalian, insect, fish and plant cells ${ }^{[6]}$. A GFP variant, GFPuv, is 18 times brighter than regular GFP and can be easily detected by the naked eye when excited with standard, long-wave UV light. GFP K-9 (or "G," as I affectionately call it) will literally have a colorful personality and will be a welcome member of my family. Its creation may be years or decades away, because it faces several obstacles, among them the mapping of the dog genome. The number of genes in the entire dog genome is estimated at about $100,000^{[7]}$. However, collaborative research is under way to map the canine genome, the results of which will eventually enable precision work at the level of canine morphology and behavior. Independently of the subtle phenotypic alteration, i.e., the delicate coat color change, GFP K-9 will eat, sleep, mate, play and interact with other dogs and humans normally. It will also be the founder of a new transgenic lineage.

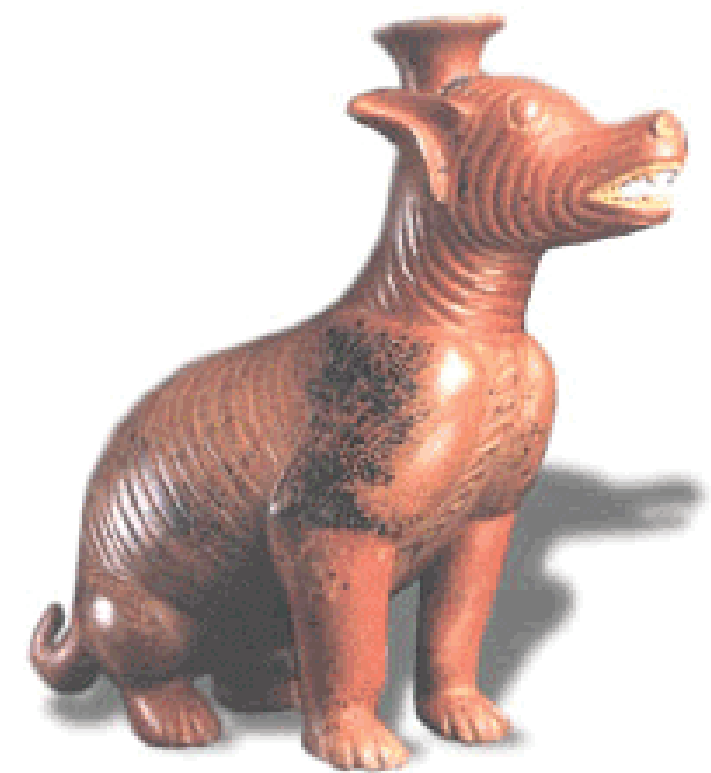

Terra cotta Colima dog, circa 700 B.C. - 200 A.D, representing the Mexican hairless dog, a possible GFP K-9 breed.

While at first the GFP K-9 project may seem completely unprecedented, human direct influence on dog evolution goes back at least 15,000 years ${ }^{[8]}$. In fact, the very existence of the domesticated dog we know today, with approximately 150 recognized breeds, is likely due to very early human-induced selective breeding of adult wolves that retained immature characteristics (a process known as neoteny). The similarities of physiognomy and behavior between the immature wolf and the adult dog are remarkable. Barking, for example, is typical of adult dogs but not adult wolves. The dog's head is smaller than the wolf's and more closely resembles that of an immature wolf. There are many other examples, including the very significant fact that dogs are also interfertile with wolves. After centuries of natural selective breeding, a turning point in human breeding of dogs took place in 1859, when the first exhibition of dogs prompted appreciation for their unique visual appearance. The search for visual 6. NIEDZ; RANDALL P., SUSSMAN; MICHAEL R.; SATTERLEE, J. S. (1995). "Green fluorescent protein: an in vivo reporter of plant gene expression". Plant Cell Reports, 14:403-406. AMSTERDAM, A., LIN, S.; HOPKINS, N. (1995). "The Aequorea victoria green fluorescent protein can be used as a reporter in live zebrafish embryos". Devel. Biol. 171:123-129. PINES, J. (1995). "GFP in mammalian cells". Trends Genet. 11:326-327. HOLDEN, C. (1997). "Jellyfish light up mice". Science. 277: 41. IKAWA, M.; YAMADA, S.; NAKANISH, T.; OKABE, M. (1998). "Green mice' and their potential usage in biological research". FEBS Letters, 430.1-2, p. 83. CORMACK, B. P., BERTRAM C., EGERBOM, M.; GOLD, N. A.; FALKOW, S.; BROWN, A. J. (1997). "Yeast-enhanced green fluorescent protein (yEGFP): a reporter of gene expression in Candida albicans". Microbiology. 143: 303-311. YEH, E.; GUSTAFSON, K.; BOULIANNE, G. L. (1995). "Green fluorescent protein as a vital marker and reporter of gene expression in Drosophila". Proc. Natl. Acad. Sci. USA, 92:7036-7040. 7. Two key obstacles to the creation of GFP K-9 are gene targeting technology and in-vitro fertilization for dogs. These obstacles are on the verge of being overcome. On September 1999, PPL Therapeutics announced the creation of the first higher transgenic mammal by targeted gene manipulation. See: FOX, S (1999). "European Roundup", Genetic Engineering News, p. 54. The Dog Genome project will further contribute to this work. See: THORPE-VARGAS, S. COILE; D. CAROLINE, D.; CARGIL, J. (1998). "Variety Spices Up The Canine Gene Pool". Dog World, 83: 5, p. 27. At last, in-vitro fertilization for dogs will be resolved by the "Missyplicity Project". While there is a significant difference between a cloned dog and a transgenic dog, it is worth mentioning that the "Missyplicity Project" aims at producing the first cloned dog, from a mutt pet called Missy (mixed border collie and husky). In August of 1998 a wealthy couple (Mr. and Mrs. John Sperling) donated \$2.3 million to Texas A \& M University to implement the project, with a two-year deadline. The project team is comprised of scientists Mark Westhusin, Duane Kraemer, and Robert Burghardt. For information on the "Missyplicity Project", see: http://www.missyplicity.com. urlil] $^{\text {Since }}$ green fluorescent protein will not express in hair (because hair has no cells; it is basically extruded protein), hairless dogs are the best candidates for the GFP K-9 project. Breeds of hairless dogs include: American Hairless Terrier, Mexican Xoloitzcuintli (or "Xolo"), Peruvian Inca Orchid, and the Argentinian Pila. For a general reference on pre-Columbian hairless dogs, see: FERNANDEZ DE CORDOBA, Joaquin (1945, March). "Los Perros Pre-colombianos de América". Journal: El Hijo Prodigo. Mexico. Specific contemporary references on hairless dogs can be found in: WHITNEEY; LEON, F.; D.V.M. (1948). How to Breed Dogs, Revised Edition. New York: Howell Book House, Inc., 11th Print

8. THURSTON, M. E. (1996). The Lost History of the Canine Race: Our 15,000-Year Love Affair with Dogs. Kansas City: Andrews \& McMeel. 
consistency and for new breeds led to the concept of pure breed and to the formation of different groups of founding dogs. The practice is with us today and is responsible for many of the dogs we see in homes everywhere. The results of indirect genetic control of dogs by breeders are proudly expressed on the pages of the canine trade press. A quick look at the marketplace reveals ads for bulldogs "engineered for protection", mastiffs with a "careful genetic breeding program", dogos with an "exclusive bloodline", and Dobermans with a "unique genetic blueprint". Breeders aren't writing the genetic code of their dogs yet, but they are certainly reading and recording it. The American Kennel Club, for example, offers a DNA Certification Program to settle questions of purebred identification and parentage.

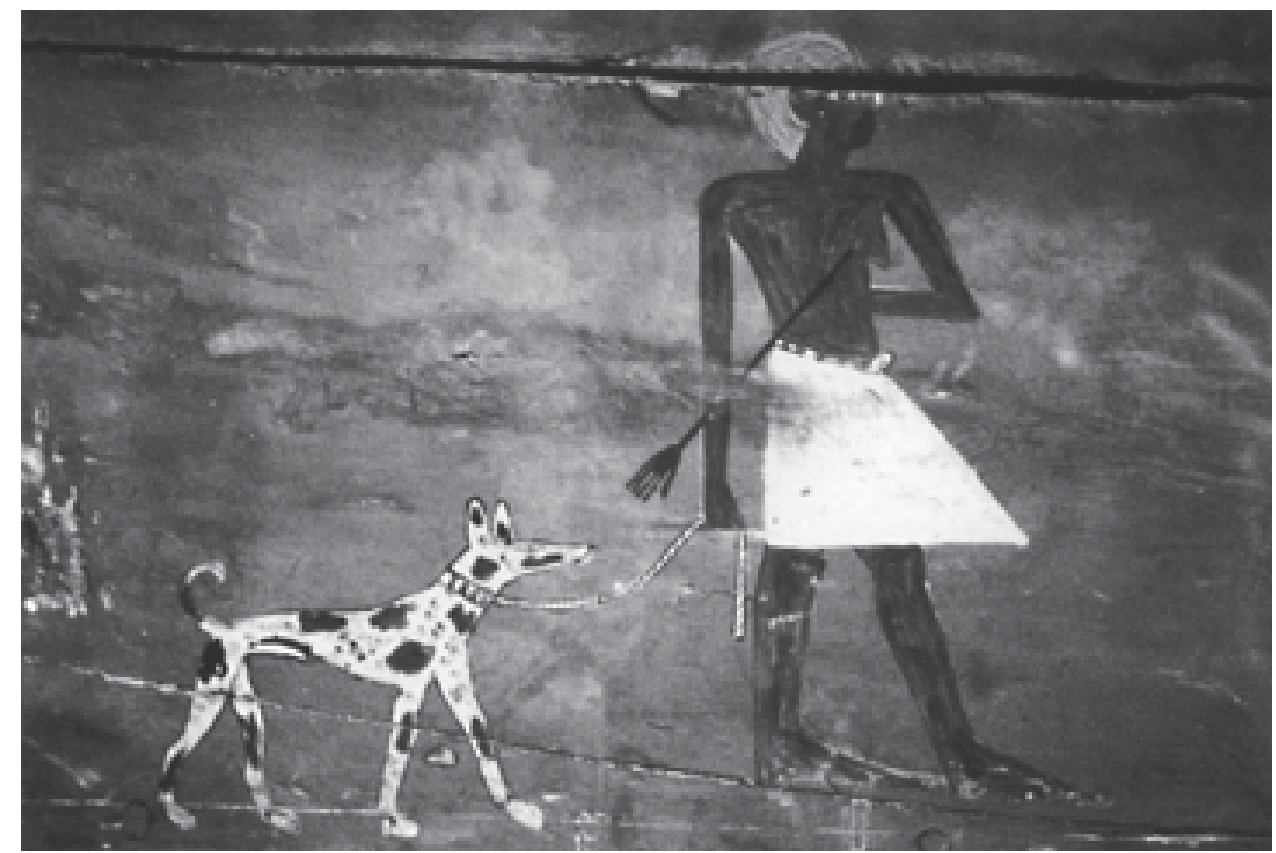

This painted detail appears on an outer face of the wooden coffin of Khuw. The deceased leads his dog on a leash. From the tomb of Khuw at Asyut, Egypt. Twelfth Dynasty (1991-1783 B.C.). Photo: Patrick Francis Houlihan

If the creation of dogs has long historical roots, more recent but equally integrated into our daily experience is our use of hybrid living organisms. A case in point is the well-known work of botanist and scientist Luther Burbank (1849-1926) who invented many new fruits, plants, and flowers ${ }^{[9]}$. In 1871, for example, he developed the Burbank potato (also known as the Idaho potato). Because of its low moisture and high starch content, it has excellent baking qualities and is perfect for French fries. Since Burbank, artificial selective breeding of plants and animals has been a standard procedure widely used by farmers, scientists, and amateurs alike. Selective breeding is a long-term technique based on the indirect manipulation of the genetic material of two or more organisms and is responsible for many of the crops we eat and the livestock we raise. Domestic ornamental plants and pets thus invented are already so common that one rarely realizes that a loved animal or a flower offered as a sign of affection are the practical results of concerted scientific effort by humans. Hybrid Teas, for example are the typical roses found at the Florist Shop \#the classic image of the rose. The first Hybrid Tea was 'La France', raised by Giullot in 1867. A cherished companion such as the Catalina macaw, with its fiery orange breast and green-and-blue wings, does not exist in nature. Aviculturists mate blue-and-gold macaws with scarlet macaws to create this beautiful hybrid animal ${ }^{[10]}$.

9. BURBANK, L. (1927). The Harvest Of The Years. Boston, New York: Houghton Mifflin. DREYER, P. (1993). A gardener touched with genius: the life of Luther Burbank. Santa Rosa, Calif.: L. Burbank Home \& Gardens.

10. The common roses of the twentieth century, such as Hybrid Teas, Floribundas and Grandifloras, were created by crossing the European Roses and the Chinas, Teas, and Meditteranean types, and many others during the 1700's and 1800's. See: BENNETT, J. H. (1965). Experiments in Plant Hybridisation. London: Oliver and Boyd, and BEALES, P.(1991). Roses. Collins-Harvill: HarperCollins. On a trip to the Sentosa Island, in Singapore, in 1998, I had the opportunity to interact playfully with a Catalina macaw, perched first on my shoulder and then on my forearm. I was able to appreciate its distinct coloration and to observe and appreciate its interaction with other macaws and humans. A description of the Catalina macaw and other hybrids can be found in:

LANTERMANN, W. (1995). Encyclopedia of Macaws. Neptune City, NJ: T.F.H.. p.173. See also: DECOTEAU, A. E. (1982). Handbook of Macaws. Neptune City, NJ: T.F.H.. Other examples of beautiful birds invented by humans which don't exist anywhere in the wild are the Harlequin Macaw (hybrid derived from breeding a Blue and Gold and a Green Winged) and the Parisian Frilled Canary, which has oddly frilled feathers. 


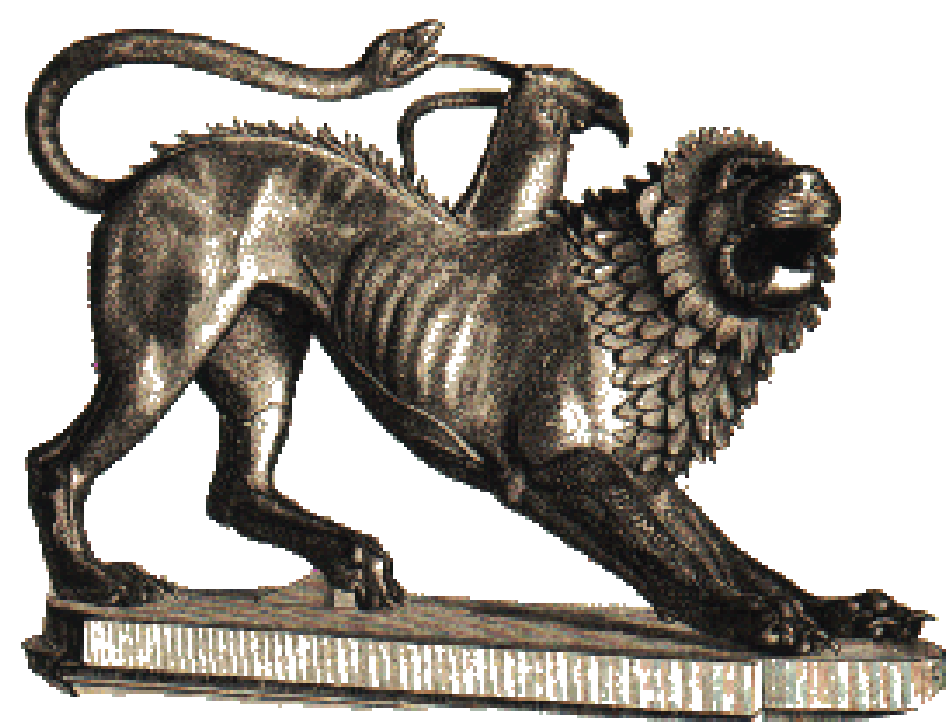

The classic Chimera of Arezzo, the best known image of the myth. The Chimera of Arezzo is a bronze statue of Etruscan origin (c. 5th century BC), approximately $80 \mathrm{~cm} \mathrm{(32")} \mathrm{in}$ height. It was found near Arezzo, in Italy, in 1553. Collection Archeological Museum, Firenze. Reproduced with permission of the Archeological Museum, Firenze.

This is not at all surprising, considering that cross-species hybrid creatures have been part of our imaginary for millennia. In Greek mythology, for example, the Chimera was a fire-breathing creature represented as a composite of a lion, goat, and serpent. Sculptures and paintings of chimeras, from ancient Greece to the Middle Ages and on to modern avant-garde movements, inhabit museums worldwide. Chimeras, however, are no longer imaginary; today, nearly 20 years after the first transgenic animal, they are being routinely created in laboratories and are slowly becoming part of the larger genescape. Some recent scientific examples are pigs that produce human proteins ${ }^{[11]}$, plants that produce plastic ${ }^{[12]}$, and goats with spider genes designed to produce a strong and biodegradable fabric ${ }^{[13]}$. While in ordinary discourse the word "chimera" refers to any imaginary life form made of disparate parts, in biology "chimera" is a technical term that means actual organisms with cells from two or more distinct genomes. A profound cultural transformation takes place when chimeras leap from legend to life, from representation to reality.

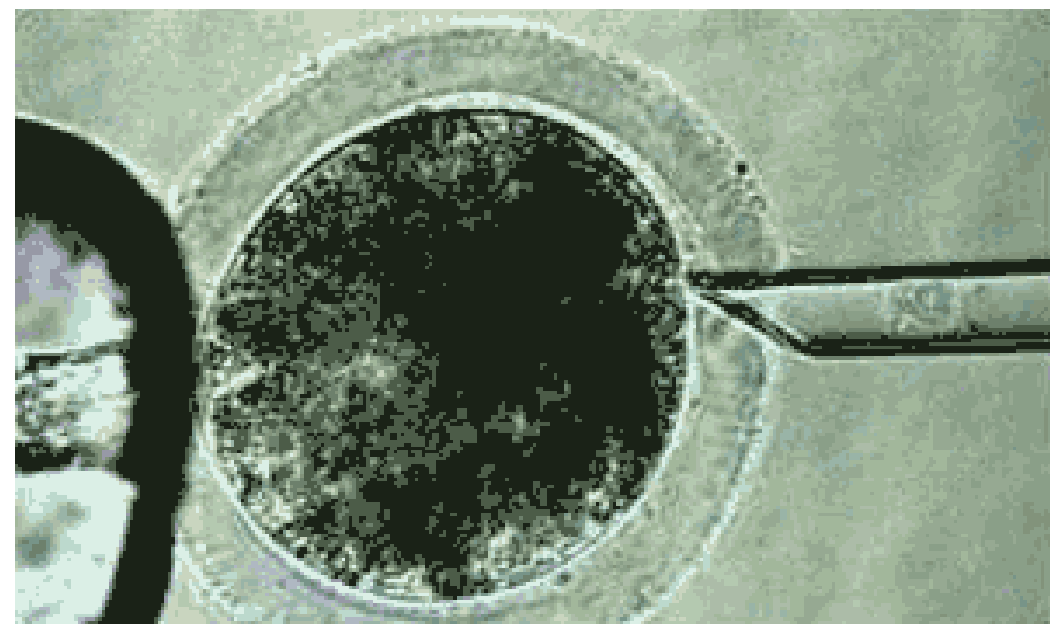

GFP K-9 will be produced with a technique called microinjection. The DNA construct will 11. COZZI, E.; WHITE, DJG. (1995). "The generation of transgenic pigs as potential organ donors for humans". Nature Medicine, 1, p. 964-966. 12. MOORE, S. K. (1997). "Natural Synthetics: Genetically engineered plants produce cotton/polyester blends and nonallergenic rubber". Scientific American, p. 36-37

13. COHEN, P. (1998). "Spinning Steel: Goats and Spiders are working together to create a novel material". New Scientist, 160: 2155, p. 11. Another combination of insect and mammal is a mouse with fly genes. In this case, the research has the goal of demonstrating that the biochemical activity utilized in mouse to mediate brain development has been retained by certain kinds of proteins across the phyla. See: HANKS, M. C.; LOOMIS, C. A.; HARRIS, E.; TONG C.; ANSON-CARTWRIGHT, L.; AUERBACH, A.; JOYNER, A. (1998). "Drosophila engrailed can substitute for mouse Engrailed1 function in mid-hindbrain, but not limb development". Development, 125: 22, p.4521-4530. 
be microinjected in a pronuclear embryo, which will be used for implantation and production of a founder GFP transgenic dog.

Likewise, there is a clear distinction between breeding and genetic engineering. Breeders manipulate indirectly the natural processes of gene selection and mutation that occur in nature. Breeders are unable, therefore, to turn genes on or off with precision or to create hybrids with genomic material so distinct as that of a dog and a jellyfish. In this sense, a distinctive trait of transgenic art is that the genetic material is manipulated directly: the foreign DNA is precisely integrated into the host genome. In addition to genetic transfer of existing genes from one species to another, we can also speak of "artist's genes," i.e., chimeric genes or new genetic information completely created by the artist through the complementary bases A (adenine) and $\mathrm{T}$ (thymine) or C (cytosine) and G (guanine). This means that artists now can not only combine genes from different species but easily write a DNA sequence on their word processors, email it to a commercial synthesis facility, and in less than a week receive a test tube with millions of molecules of DNA with the expected sequence. 


\section{Fertilized egg}
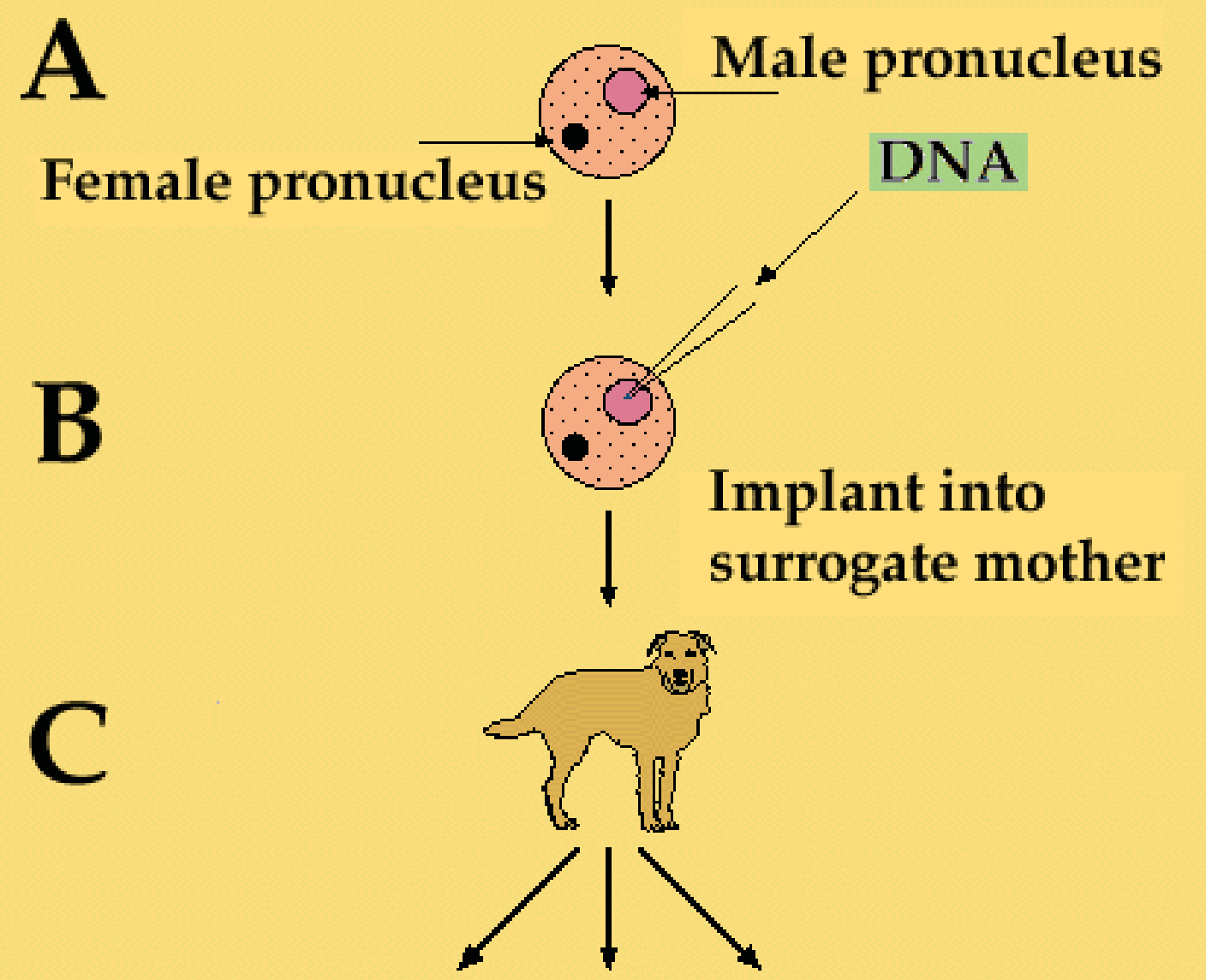

D

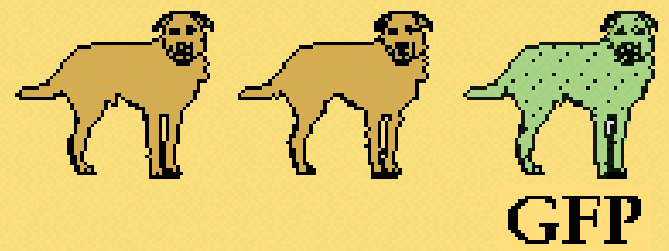

\section{Offspring}

Production of GFP K-9. (A) Fertilized eggs are removed from a female and (B) the DNA carrying the GFP gene is injected into the male pronucleus. (C) The eggs are then implanted into a carrier. (D) Some of the pups express the GFP gene.

Genes are made of deoxyribonucleic acid (DNA) molecules. DNA carries all the genetic information necessary for a cell's duplication and for the building of proteins. DNA instructs another substance (ribonucleic acid, or RNA) how to build the proteins. RNA carries on the task using as its raw material cellular structures called ribosomes (organelles with the function of bringing together the amino acids, out of which proteins are made). Genes have two important components: the structural element (which codes for a particular protein) and the regulatory element ("switches" that tell genes when and how to perform). Transgene constructs, created by artists or scientists, also include regulatory elements that promote expression of the transgene. The foreign DNA may be expressed as extrachromosomal satellite DNA or it may be integrated into the cellular chromosomes. Every living organism has a genetic code that can be manipulated, and the recombinant DNA can be passed on to the next generations. The artist 
literally becomes a genetic programmer who can create life forms by writing or altering this code. With the creation and procreation of bioluminescent mammals and other creatures in the future $^{[14]}$, dialogical interspecies communication will change profoundly what we currently understand as interactive art. These animals are to be loved and nurtured just like any other animal.

The result of transgenic art processes must be healthy creatures capable of as regular a development as any other creatures from related species ${ }^{[15]}$. Ethical and responsible interspecies creation will yield the generation of beautiful chimeras and fantastic new living systems, such as plantimals (plants with animal genetic material, or animals with plant genetic material) and animans (animals with human genetic material, or humans with animal genetic material).

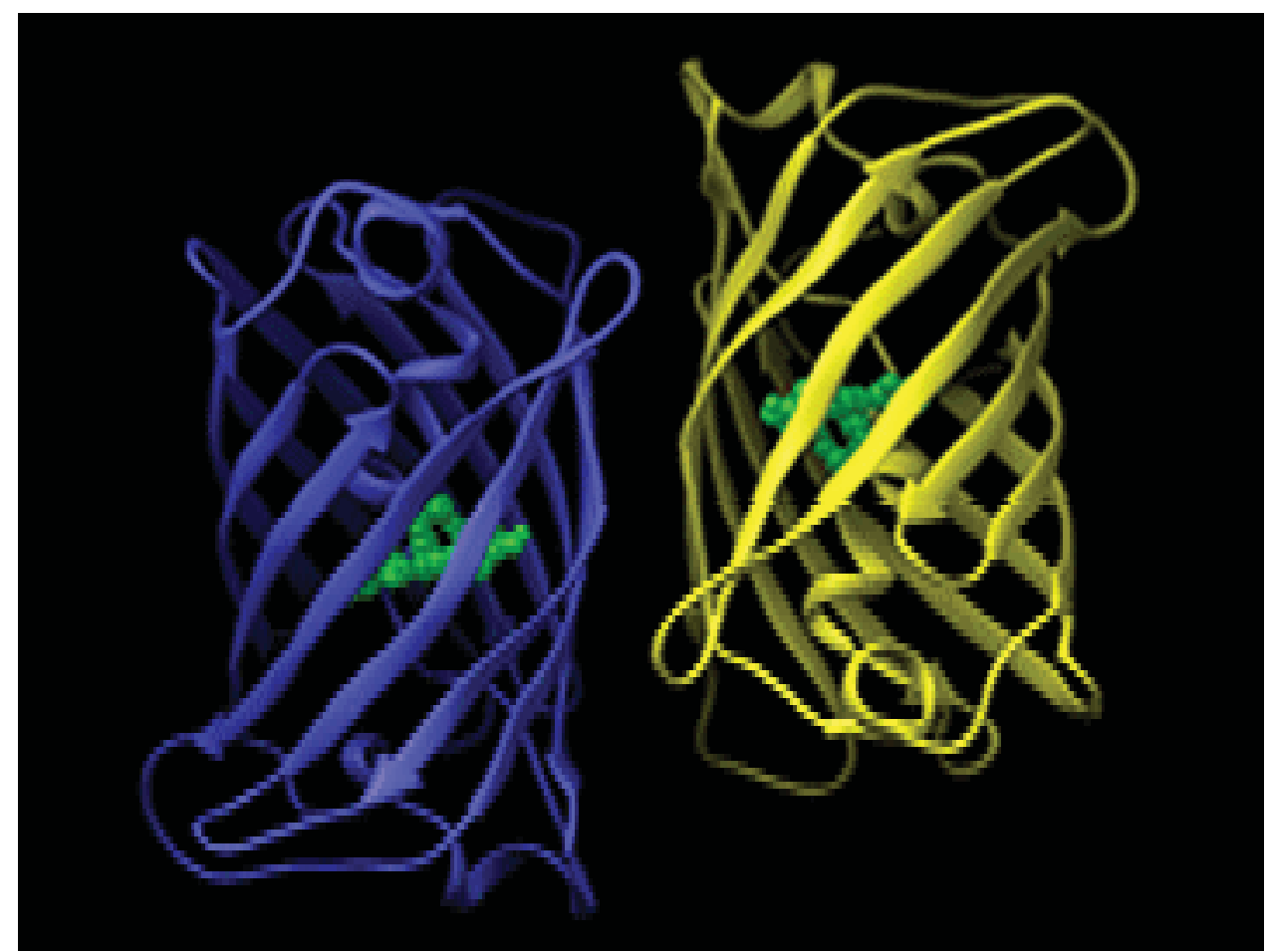

GFP K-9, Eduardo Kac, 1998/1999. Green Fluorescent Protein structure solved by Fan Yang and George N. Phillips, Jr. of Rice University and Larry Moss of Tufts University School of Medicine. Figure designed and rendered by Tod D. Romo of Rice University.

As genetic engineering continues to be developed in the safe harbor of scientific rationalism, nourished by global capital, it unfortunately remains partially sheltered from larger social issues, debates on ethics, and local historical contexts. The patenting of new animals created in the ${ }^{l a b}{ }_{[}^{16]}$ and of genes of foreign peoples ${ }^{[17]}$ are particularly complex topics \#a situation often aggravated, in the human case, by the lack of consent, equal benefit, or even understanding of the processes of appropriation, patent, and profit on the part of the donor. Since 1980 the U.S. Patent and Trademark Office (PTO) granted several transgenic animal patents, including patents for transgenic mice and rabbits. Recently the debate over animal patents has broadened to encompass patents on genetically engineered human cell lines and synthetic constructs (e.g., "plasmids") incorporating human genes. The use of genetics in art offers a reflection on these new developments from a social and ethical point of view. It foregrounds

14. BREM, G.; MÜLLER, M. (1994). "Large Transgenic Mammals", in MACLEAN, N. (ed.) Animals With Novel Genes. New York: Un. of Cambridge. p. 179-244; IKAWA, M.; KOMINAMI, K.; YOSHIMURA, Y.; TANAKA, K.; NISHIMUNE, Y.; OKABE, M. (1995). "Green fluorescent protein as a marker in transgenic mice". Devel. Growth Differ, 37:455-459. YOUVAN, D. C. (1995). "Green fluorescent pets". Science, 268: 264. PENNISI, E. (1997, 1 August). "Transgenic Lambs From Cloning Lab". Science, 277, p.631.

15. DYSON, A.; HARRIS, J. (eds.) Ethics and Biotechnology. New York: Routledge. VAN ZUTPLEN, L. F. M.; VANN DER MEER, M. (eds). (1995). Welfare Aspects of Transgenic Animals. Berlin, New York: Springer Verlag.

16. SCHNEIDER; KEITH (1987). "New Animal Forms Will Be Patented". New York Times. ADLER, R.G. (1988). "Controlling the Applications of Biotechnology: A Critical Analysis of the Proposed Moratorium on Animal Patenting". Harvard Journal of Law and Technology, vol. 1. ANDREWS, E. L. (1991, October 21). "U.S. Seeks Patent on Genetic Codes, Setting Off Furor". New York Times, A1, A12. MARSHALL, E. (1997). "Companies Rush to Patent DNA", Science, 275. p. 780-781. MARSHALL, E. "The Mouse That Prompted a Roar". Science, 277 p. 24-25. 17. PENENBER, A.L. (1996). "Gene Piracy". 21C-Scanning the Future, 2, p. 44-50. 
related relevant issues such as the domestic and social integration of transgenic animals, arbitrary delineation of the concept of "normalcy" through genetic testing, enhancement and therapy, health insurance discrimination based on results of genetic testing, and the serious dangers of eugenics.

As we try to negotiate current disputes, it is clear that transgenetics will be an integral part of our existence in the future. It will be possible, for example, to harness the glow of the jellyfish protein for optical data storage devices ${ }^{[18]}$. Transgenic crops will be a predominant part of the landscape, transgenic organisms will populate the farm, and transgenic animals will become part of our expanded family. For better or worse, vegetables and animals we eat will never be the same. Genetically altered soybeans, potatoes, corn, squash, and cotton have been widely planted and consumed since $1995^{[19]}$. The development of "plantibodies," i.e., human genes transplanted into corn, soy, tobacco, and other plants to produce acres of pharmaceutical-quality antibodies, promises cheap and abundant much needed proteins ${ }^{[20]}$. While in many cases research and marketing strategies place profit above health concerns (the risks of commercialization of unlabeled and potentially sickening transgenic food can't be ignored) ${ }^{[21]}$, in others biotechnology seems to offer real promises of healing in areas presently difficult to treat effectively. Pigs are a case in point. Because porcine physiological function is similar in many ways to that of humans, and because society at large agrees to breed and slaughter pigs for the food industry (unlike nonhuman primates, for example), medicine is experimenting with genetically altered pigs [see 11]. These pigs produce human proteins that prevent rejection and are being tested for liver and heart transplant (unmodified pig livers are already used as a "bridge" to sustain patients waiting for a human donor), for brain transplant (fetal pig neural cells are used to reconnect the nerve tissue in Parkinson's patients), and to cure diabetes (through the transplant of insulin-producing beta cells) ${ }^{[22]}$. In the future we will have foreign genetic material in us as today we have mechanical and electronic implants. In other words, we will be transgenic. As the concept of species based on breeding barriers is undone through genetic engineering ${ }^{[23]}$, the very notion of what it means to be human is at stake ${ }^{[24]}$. However, this does not constitute an ontological crisis. To be human will mean that the human genome is, not a limitation, but our starting point. First published in Leonardo Electronic Almanac (ISSN 1071-4391), Volume 6, Number 11, 1998.

18. DICKSON, R. M., et al. (1997). "On/off blinking and switching behaviour of single molecules of green fluorescent protein". Nature 388, p. 355-358. Letters to Nature. For a popular account of the potential use of this technology, see: TATTERSON, K.G. (1997, September). "Jellyfish Genes Eyed for Optical Storage". Photonics Spectra.

19. BROWN, K. S. (1995). "With New Technology, Researchers Engineer A Plant For Every Purpose". The Scientist, 9:19. p. 14-15. RISSLER, J.; MELLON, M. (1996). The Ecological Risks of Engineered Crops. Cambridge: MIT Press.

(1996). The Ecological Risks of Engineered Crops. Cambridge: MIT Press. 20. GIBBS, W. W. (1997, November). "Plantibodies: Human antibodies produced by field crops enter clinical trials". Scientific American, November 1997. p. 4
21. TOKAR, B. (1998, September/October). "Monsanto: A Checkered History". In: The Monsanto Files, special issue of The Ecologist, 28: 5, p. 254-261. 21. TOKAR, B. (1998, September/October). "Monsanto: A Checkered History". In: The Monsanto Files, special issue of The Ecologist, 28: 5, p. 254-261.
KIMBRELL, A. (1998, September/October) "Why Biotechnology and High-Tech Agriculture Cannot Feed the World", in The Monsanto Files, special issue of The Ecologist, 28: 5, p. 294-298.

22. MAKOWKA; CRAMMER, DV; HOFFMAN, A.; BREEDA, M.; SHER, G.; EIRAS-HREHA, G.; TUSO, PJ; YASUNAGA, C.A.; COSENZA, G.; CHAPMAN, F.A.; PODESTA, L. (1995) "The use of a pig liver xenograft for temporary support of a patient with fulminant hepatic failure". Transplantation, 59: 1654-1659. WHITE, D.J.G.; LANGFORD, G.A.; COZZI, E., YOUNG, V.J. (1995). "Production of pigs transgenic for human DAF: A strategy for xenotransplantation". Xenotransplantation, 2: 213-217. COOPER, D.K.C.; KEMP, E.; PLATT, J.L., WHITE, D.J.G.(eds.). (1997). Xenotransplantation: the transplantation of organs and tissues between species. Berlin, New York: Springer.

23. Some exemplary cases are the production of rat sperm in the testes of a mouse (which clearly suggests that human sperm could also be produced in the testicles of a rodent), the innitial division of a human cell in the egg of a cow, and the creation of an embryonic clone of an adult woman in South Korea. See: CLOUTHIER, D. E., et al. (1996). "Rat spermatogenesis in mouse testis". Nature, 381. p. 18-421. ROBL, J.; JERRY, M; STICE, S; CIBELLI, J. (1998). "Letters to Nature"; Response "Quiescence in Nuclear Transfer". Science, 281: 5383. p. 1611; BBC Online. (1998, December 16). "S. Korean scientists claim human cloning success", (http://www.news.bbc.co.uk ${ }^{[u r l 2]}$ ).

24. In an article for the New Scientist (October 23, 1999), entitled "We Have the Power", Andy Coghlan reported that a Canadian company, Chromos Molecular Systems of Burnaby, British Columbia, presented preliminary results of experiments with mice given an artificial chromosome. He wrote: "By taking cell sample and exposing them to fluorescent dyes that bind to different parts of the chromosome, Chromos's scientists were able to discover which animals had accepted the chromosome. When the mice carrying the extra chromosome were crossed with normal mice, it was inherited in exactly the same way as the animals' natural chromosomes." This is an indication that human germline gene therapy is becoming a practical possibility. It shows that one day it might be possible, for medical reasons, to add synthetic genes to human embryos which otherwise would develop with serious or fatal congenital defects. 


\section{URL list:}

[url1]: http://www.missyplicity.com

[url2]:http://www.news.bbc.co.uk

\section{Related links:}

$\rightarrow$ Eduardo Kac:

http://www.ekac.org

"n $\rightarrow$ The Eighth Day:

http://www.ekac.org/8thday.html

$u$ Genesis:

http://www.ekac.org/geninfo.html

$m \rightarrow$ GPF Bunny:

http://www.ekac.org/gfpbunny.html

" $\rightarrow$ Bibliography about transgenic art:

http://www.ekac.org/transartbiblio.html

$m \rightarrow$ Publicacions de i sobre Eduardo Kac:

http://www.ekac.org/publications.html

\section{Partners:}

\section{Recommended citation:}

KAC, Eduardo (2002). "Transgenic Art". Artnodes, issue 1 [article online].

DOI: http://dx.doi.org/10.7238/a.v0i1.676

$-10$

ISSN 1695-5951 Legal deposit B-52019-2002

\section{UOC}

